\title{
Penanganan Limbah Baglog Jamur Tiram (Pleurotus osteatus) di Desa Bodag Kecamatan Kare Kabupaten Madiun
}

\author{
Praptiningsih Gamawati Adinurani*1, Sri Rahayu ${ }^{2}$ \\ 1,2Program Studi Agroteknologi, Fakultas Pertanian, Universitas Merdeka Madiun \\ *e-mail: praptiningsih@unmer-madiun.ac.id ${ }^{1}$
}

\begin{abstract}
The sawmill industry in the village of Bodag, Kare Subdistrict, Madiun Regency causes an abundance of sawdust. The waste can be used as a growing media for oyster mushroom cultivation. This waste problem can be overcome, but new issues arise with the production of mushroom growing media (baglog). Baglog waste generated in one harvest more or less (1 - 2) t. Limited knowledge and skills in the use of baglog waste is a problem. The community service program aims to improve the skills of mushroom farmers to yield products made from baglog waste. Activities to overcome problems using counselling methods, discussions, practices and assistance. Initial counselling of the meeting about the prospects for the cultivation of oyster mushrooms continued handling baglog which has expired so that it does not become waste that pollutes the environment. Target and outputs of activities, namely after farmers follow counselling on managing waste and making various waste products, farmers can produce compost, animal feed and fuel made from baglog waste which can increase farmer's income.
\end{abstract}

Keywords: old baglog, contaminated baglog, environmental pollution, baglog compost

\begin{abstract}
Abstrak
Industri penggergajian kayu di desa Bodag Kecamatan Kare Kabupaten Madiun menyebabkan berlimpahnya serbuk gergaji kayu. Limbah tersebut dapat digunakan sebagai media tanam budidaya jamur tiram. Permasalahan limbah ini dapat diatasi namun timbul masalah baru dengan dihasilkannya limbah media tanam jamur (baglog). Limbah baglog yang dihasilkan dalam satu kali panen kurang lebih (1 - 2) t.. Keterbatasan pengetahuan dan keterampilan pemanfaatan limbah baglog merupakan suatu permasalahan. Tujuan program pengabdian kepada masyarakat adalah meningkatkan keterampilan petani jamur untuk menghasilkan produk berbahan limbah baglog. Kegiatan mengatasi permasalahan menggunakan metode penyuluhan, diskusi, praktek dan pendampingan. Penyuluhan awal pertemuan tentang prospek budidaya jamur tiram dilanjutkan penanganan baglog yang telah habis masa tanamnya agar tidak menjadi limbah yang mencemari lingkungan. Sesuai target dan luaran kegiatan yaitu setelah petani mengikuti penyuluhan penanganan limbah dan pembuatan berbagai produk limbah maka petani dapat memproduksi kompos, pakan ternak dan bahan bakar berbahan baku limbah baglog yang dapat meningkatkan pendapatan petani.
\end{abstract}

Kata kunci: baglog tua; baglog terkontaminasi; pencemaran lingkungan; kompos baglog

\section{PENDAHULUAN}

Desa Bodag Kecamatan Kare Kabupaten Madiun merupakan desa di lereng Gunung Wilis, wilayahnya berbatasan dengan hutan. Penduduknya bermata pencaharian bertani, berkebun dan beternak. Pada tahun 2019, Desa Bodag mendapat bimbingan dalam budidaya jamur tiram putih yang dikelola oleh kelompok tani Rejotani dan Mulyotani. Tingginya permintaan jamur tiram menjadi peluang usaha yang baik bagi kedua kelompok tani tersebut. Bisnis budidaya jamur tiram sangat menggiurkan dan modal yang diperlukan tidak terlalu banyak. Petani dapat memperoleh keuntungan relatif banyak dalam waktu kurang dari setahun. Hal ini disebabkan siklus usaha jamur tiram mulai dari pembuatan media tanam sampai panen perdana hanya memerlukan waktu kurang dari dua bulan. Selain itu, waktu tumbuh jamur tiram lebih pendek dibanding jamur pangan lainnya dan media tanamnya hanya memerlukan pasteurisasi bukan sterilisasi sehingga biaya produksinya lebih rendah. Jamur tiram dapat dijual dalam bentuk segar ataupun bentuk olahan seperti nuget, rendang, crispy atau abon jamur tiram (Susi et al, 2017)

Budidaya jamur memerlukan media tanam yang dinamakan baglog. Bahan baku baglog berupa serbuk gergaji kayu dicampur kapur dan bekatul. Jenis serbuk kayu yang digunakan dalam proses pembuatan baglog tergantung pada ketersediaan bahan kayu di daerah petani jamur. Namun serbuk kayu yang paling banyak digunakan sebagai media tanam adalah serbuk gergaji 
kayu sengon. Selain serbuk gergaji kayu, komposisi media tanam jamur ada yang ditambahkan bahan lain, seperti tepung jagung, glukosa, dan gips (Muchlisin, 2013, Jazuri, 2013, dan Redaksi Trubus, 2014, ). Semakin banyak jumlah petani budidaya jamur tiram secara tidak langsung akan menghasilkan banyak limbah baglog. Total limbah yang dihasilkan tergantung dari besar kecilnya usaha dan tipe usaha. Semakin besar produksi jamur tiram maka semakin banyak pula jumlah limbah baglog. Rosmauli, dkk. (2015), menyatakan bahwa 4.000 baglog dalam waktu (3 - 4) bulan pasca panen dapat menghasilkan limbah sekitar $1 \mathrm{t}$, sehingga kapasitas kurang lebih 5000 baglog pada petani jamur desa Bodag akan menghasilkan limbah lebih dari 1 t. Sebenarnya petani budidaya jamur telah mengatasi permasalahan limbah gergaji kayu dengan memanfaatkannya sebagai media tanam, namun setelah limbah gergaji termanfaatkan masih timbul masalah baru berupa limbah baglog.

Limbah baglog jamur tiram merupakan media tanam yang sudah habis masa penennya. Limbah tersebut dapat berupa baglog tua dan atau baglog terkontaminasi yang dibuang oleh petani jamur. Limbah baglog yang sudah tidak produktif jika tidak dimanfaatkan akan menjadi sampah yang menumpuk, menimbulkan bau tidak sedap, dan menjadi sumber pencemaran. Adanya limbah yang melimpah tanpa ada upaya pengolahan dari petani jamur tiram mengakibatkan pencemaran lingkungan disekitar pembuangan limbah. Limbah tersebut dikhawatirkan menjadi sarang hama penyakit dan dapat menyerang jamur yang dibudidayakan, tanaman pertanian, ternak, dan manusia (Priyanto, 2013). Hal ini tidak akan terjadi jika limbah tersebut diberi sentuhan suatu teknologi menjadi suatu produk yang mempunyai nilai tambah.

Menurut Sulaeman (2011), bahwa limbah baglog tua masih memiliki kandungan nutrisi N (0.6 \%), P (0.7\%), K (0.02 \%), dan C-organik (49.0\%). Sedang baglog terkontaminasi mempunyai kandungan nutrisi relatif lebih tinggi yaitu N (0.8\%), P (0.8\%), K (0.16\%), dan C-organik (52.0 \%). Hal ini disebabkan unsur hara dalam limbah baglog tua sebagian besar telah dimanfaatkan oleh jamur untuk proses pertumbuhan. Meskipun demikian, unsur hara yang tersisa dalam limbah baglog masih dapat dikelola menjadi kompos, pakan ternak, media baglog baru, media belut, media ternak cacing dan sebagai bahan bakar (Rubiyah, 2012; Farhad, 2013; Priyanto, 2013; Warta, 2014; dan Triyanto, 2018).

Tujuan dari pelaksanaan program pengabdian kepada masyarakat ini adalah : (a) sosialisai dampak pembuangan limbah baglog (b) peningkatan pengetahuan pemanfaatan limbah baglog sebagai produk yang berguna, (b) membuat lingkungan bersih dari limbah baglog (c) pelatihan penanganan limbah baglog menjadi produk bermanfaat dan bernilai tambah.

\section{METODE}

Kegiatan program pengabdian kepada masyarakat dilaksanakan di desa Bodag, Kecamatan Kare Kabupaten Madiun selama bulan Juli sampai September 2019. Metode pendekatan penyelesaian permasalahan limbah baglog dengan cara mengunjungi kumbung kelompok petani jamur Rejotani dan Mulyotani, berdiskusi tentang permasalahan limbah sekaligus sosialisasi dampak pembuangan limbah. Selama pelaksanaan kegiatan, petani jamur berpartisipasi dalam penyediaan tempat, penentuan jadwal penyuluhan, pengumpulan anggota petani dan penyediaan bahan limbah yang digunakan untuk praktek pembuatan kompos, pakan ternak ataupun bahan bakar. Kegiatan penyuluhan meliputi (a) pemberian materi pengetahuan penanganan limbah baglog melalui penyuluhan dan diskusi secara langsung tentang berbagai upaya penanganan limbah baglog dan pengenalan pembuatan produk dari limbah baglog (b) pembuatan kompos, pakan ternak dan bahan bakar dari limbah baglog sesuai dengan jadwal yang telah ditentukan (d) pendampingan selama pembuatan produk dari limbah baglog selalu dilakukan, agar kendala dan permasalahan yang dihadapi petani dapat segera diatasi dan sekaligus memantau ketercapaian kegiatan. 


\section{HASIL DAN PEMBAHASAN}

Kegiatan pengabdian dilakukan pada kelompok tani Rejotani dan Mulyotani desa Bodag, Kecamatan Kare Kabupaten Madiun. Awalnya petani diberi pengetahuan tentang budidaya jamur tiram, permasalahan dan solusinya, serta pengetahuan tentang penanganan limbah baglog. Selama penyuluhan diadakan diskusi secara langsung (Gambar 1) Setelah pemberian materi dan diskusi dilanjutkan dengan pelatihan pembuatan baglog (Gambar 2).

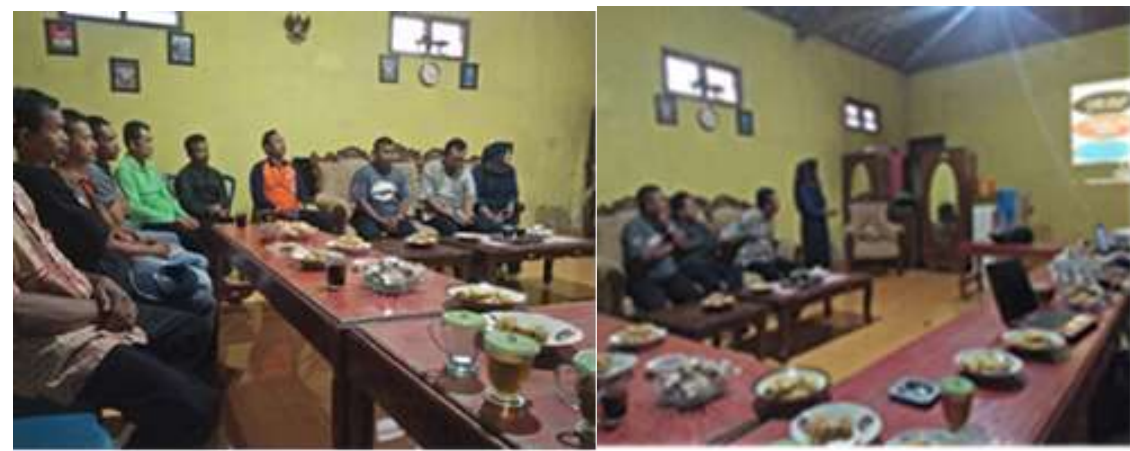

Gambar 1. Penyampaian Materi Budidaya Jamur Tiram dan Penanganan Limbah

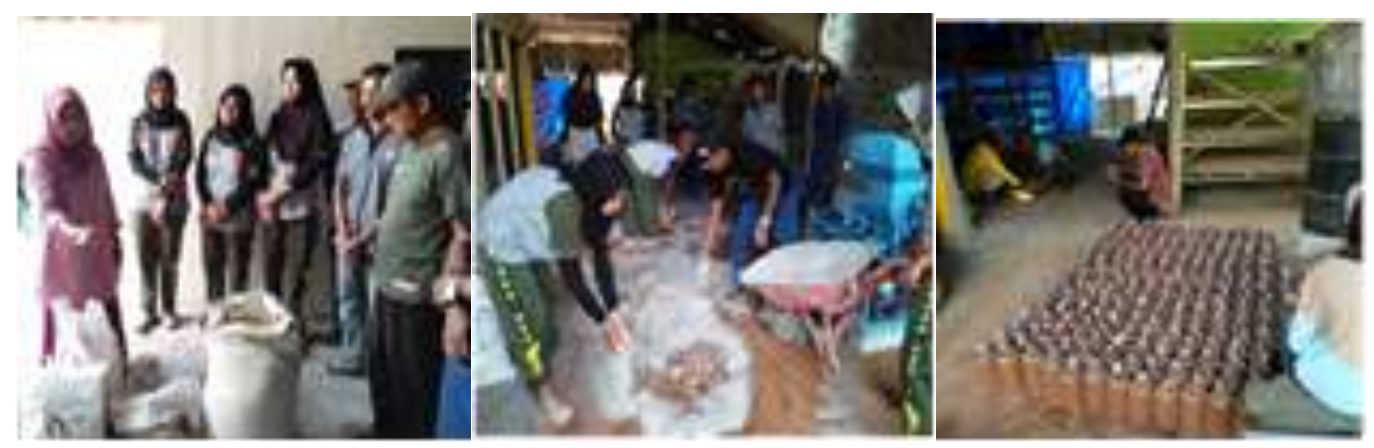

Gambar 2. Proses Pembuatan Baglog

Saat penyuluhan dijelaskan pula tentang pasca budidaya jamur yaitu penanganan limbah baglog. Terdapat dua jenis limbah baglog yaitu baglog tua dan baglog terkontaminasi (Gambar 3). Baglog tua adalah media bekas budidaya jamur yang sudah habis masa tanamnya atau sudah tidak produktif sedangkan baglog terkontaminasi merupakan baglog yang gagal tumbuh terutama saat inkubasi sehingga dipisahkan dari baglog lainnya (Maonah, 2010 dalam Sulaeman, 2011).

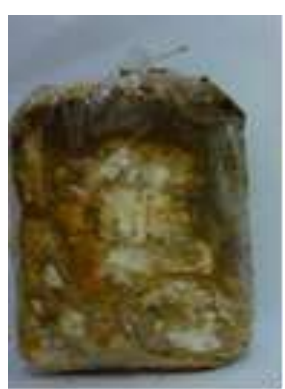

(a)

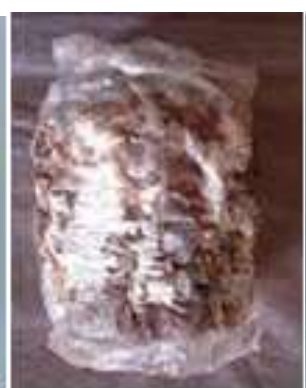

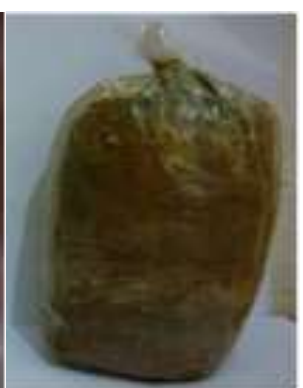

(b)

Gambar 3. Perbedaan limbah baglog tua (a) dan limbah baglog terkontaminasi (b)

Umumnya budidaya jamur menghhasilkan limbah baglog dalam jumlah banyak. Petani yang menggunakan 4.000 baglog, maka dalam waktu 3 - 4 bulan pasca panen akan menghasilkan limbah baglog sekitar \pm 1 ton (Rosmauli dkk., 2015). Masa pakai baglog tergantung dari jenis dan kekuatan serbuk kayu yang digunakan. Misalnya serbuk kayu sengon, masa pakainya sekitar 3 
bulan sedang serbuk kayu jati antara 5-6 bulan. Baglog yang sudah habis masa tanamnya, jika dibuang atau tidak dimanfaatkan akan merupakan limbah yang sangat mengganggu lingkungan dan merupakan sumber kontaminan. Namun jika diberi sentuhan tehnologi, limbah ini akan mempunyai nilai tambah karena dapat dibuat pupuk organik ( Sulaeman, 2011; dan Rubiyah, 2012), pakan ternak (Farhad, 2013), bahan bakar (Priyanto, 2013 ), daur ulang sebagai media baglog (Hadiprayitno, dkk., 2018).

Materi tentang nilai tambah limbah baglog diberikan secara teori dan secara praktek petani diberi kebebasan dalam pemanfaatan limbah sesuai dengan kondisi masing-masing petani. Selanjutnya ada pendampingan selama pembuatan produk tersebut. Petani jamur lebih banyak yang memanfaatkannya sebagai pupuk organik mengingat petani jamur banyak yang membudidayakan tanaman pangan. Namun ada sebagian yang memanfaatkan sebagai bahan bakar untuk digunakan pada proses inkubasi. Hal ini untuk mengurangi biaya pengeluaran bahan bakar. Meskipun tidak banyak petani jamur yang memiliki ternak, namun tetap disampaikan pula informasi tentang pembuatan pakan ternak. Petani tidak berminat mendaur ulang limbah baglog sebagai media tanam, karena petani khawatir produksi jamur tidak maksimal.

\section{1) Pupuk Organik Limbah Baglog}

Limbah baglog masih mempunyai kandungan unsur hara yang cukup (Sulaeman, 2011) sehingga dapat dimanfaatkan sebagai pupuk organik (Tabel 1).

Tabel 1. Kandungan Unsur Hara Limbah Baglog

\begin{tabular}{|c|c|c|}
\hline \multirow[t]{2}{*}{ Unsur Hara } & \multicolumn{2}{|c|}{ Limbah } \\
\hline & Baglog Tua & Baglog Terkontaminasi \\
\hline C $\quad(\%)$ & 49 & 52 \\
\hline$(\%)$ & 0.6 & 0.8 \\
\hline$(\%)$ & 0.7 & 0.8 \\
\hline $\mathrm{K} \quad(\%)$ & 0.02 & 0.16 \\
\hline $\mathrm{Na} \quad(\%)$ & 0.003 & 0.003 \\
\hline $\mathrm{Ca} \quad(\%)$ & 1.6 & 2.0 \\
\hline $\operatorname{Mg} \quad(\%)$ & 0.34 & 0.35 \\
\hline$M n \quad(p p m)$ & 175 & 182 \\
\hline $\mathrm{Zn} \quad(\mathrm{ppm})$ & 182 & 349 \\
\hline $\mathrm{Fe} \quad(\mathrm{ppm})$ & 1597 & 1605 \\
\hline $\mathrm{Cu} \quad(\mathrm{ppm})$ & 14 & 48 \\
\hline Rasio C/N & 83 & 66 \\
\hline KTK (me $/ 100 \mathrm{~g}$ ) & 45 & 14 \\
\hline
\end{tabular}

Petani yang kurang paham tentang limbah baglog, banyak yang menggunakan secara langsung sebagai pupuk organik. Untuk menghindari hal tersebut maka saat penyuluhan dijelaskan kelebihan dan kekurangan penggunaan limbah baglog secara langsung tanpa proses pengomposan. Diketahui bahwa kandungan unsur hara limbah baglog masih cukup untuk tanaman namun belum bisa langsung diberikan ke tanaman karena rasio atau perbandingan antara unsur $\mathrm{C}$ dan $\mathrm{N}$ (C/N) masih tinggi yaitu 83 (baglog tua) dan 66 (baglog terkontaminasi). Oleh karena itu harus dikomposkan terlebih dahulu. Penggunaan bahan organik yang belum mengalami proses dekomposisi/pengomposan yang nilai rasio $\mathrm{C} / \mathrm{N}$ lebih besar dari 25 
menyebabkan ketersediaan unsur N, P, dan K tanah menurun. Hal ini dikarenakan unsur-unsur tersebut diserap dan digunakan oleh mikroba untuk kegiatan penguraian bahan organik. Akibatnya terjadi persaingan antara tanaman dengan mikroba dalam pengambilan unsur hara $\mathrm{N}$, $\mathrm{P}$, dan K. Selain terjadi persaingan dalam pengambilan hara, proses dekomposisi/pengomposan menghasilkan energi sehingga suhu tanah meningkat dan dapat menyebabkan tanaman mati.

Pembuatan pupuk dilakukan dengan cara melepas limbah baglog dari kantong plastik dan dibersihkan dari bahan-bahan lain terutama bahan anorganik (Gambar 4). Bahan limbah baglog banyak yang menggumpal sehingga perlu diremah/dihancurkan supaya ukurannya seragam. Demikian pula kotoran ternak yang akan dicampurkan diperkecil ukurannya dengan cara digiling/ditumbuk. Kotoran ternak yang digunakan adalah kotoran ternak yang sudah mengalami fermentasi (Gambar 5 ).

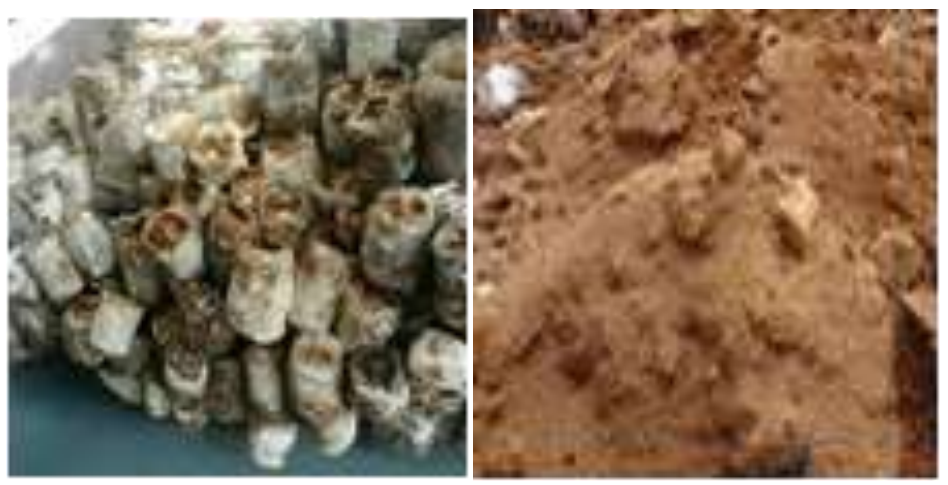

Gambar 4. Limbah Baglog Sebelum dan Sesudah Dikeluarkan dari Kantong Plastik
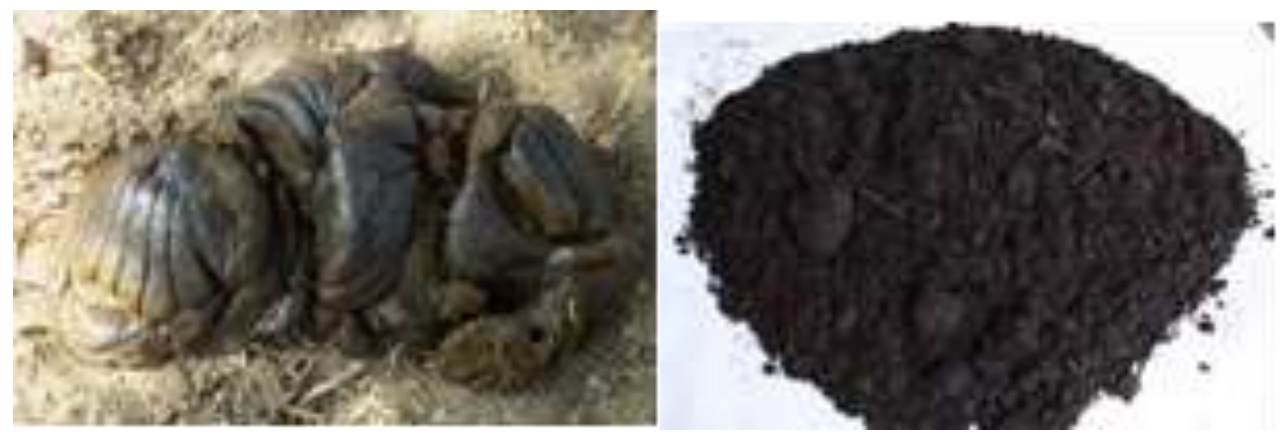

Gambar 5. Kotoran Sapi Sebelum dan Sesudah Fermentasi

Limbah baglog sebanyak $250 \mathrm{~kg}$ ditambah $100 \mathrm{~kg}$ kotoran ternak, dan $10 \mathrm{~kg}$ dedak diaduk sampai tercampur merata. Kemudian ditambahkan campuran $350 \mathrm{ml}$ EM4 (Effective Microorganism 4), 1/4 kg gula merah/gula pasir yang dilarutkan dalam air. Campuran bahan diaduk hingga merata/homogen kemudian disiram air hingga campuran bahan mempunyai kelembaban sekitar $60 \%$ kemudian ditutup terpal/plastik untuk proses pengomposan ditempat yang terhindar dari air dan matahari langsung. Proses pengomposan dapat terjadi secara aerob (penggunaan oksigen) atau anaerob (tidak ada oksigen). Petani lebih berminat pengomposan secara aerob dibanding cara anaerob, alasannya lebih sederhana dan mudah pelaksanaannya serta tidak memerlukan tempat khusus. Pada dasarnya limbah baglog telah mengalami proses pengomposan sehingga pengolahannya untuk menjadi pupuk organik tidak membutuhkan waktu lama. Oleh karena itu pembuatan pupuk organik berbahan baku limbah baglog membutuhkan waktu lebih cepat yakni sekitar 1 bulan dibanding waktu yang diperlukan pembuatan pupuk organik lainnya sekitar 2-3 bulan (Indriani, 2011 dan Hunaepi, et al, 2014). Bahan kompos dikatakan sudah terdekomposisi dengan baik atau sudah layak digunakan sebagai pupuk jika sudah terjadi perubahan warna, tekstur dan aroma. Warna berubah ke warna agak gelap (coklat 
kehitaman) atau warna gelap (hitam), sedang struktur kompos menjadi remah dan aroma tidak bau (Gambar 6).

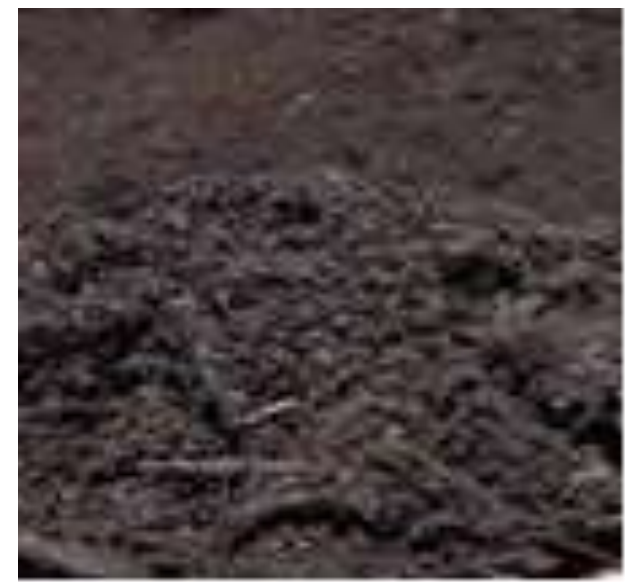

Gambar 6. Kompos Limbah Baglog

Menurut Sobari (2018), bahwa kompos limbah baglog mempunyai C/N ratio rendah dan masih terdapat unsur-unsur hara yang dibutuhkan tanaman (Tabel 2).

Tabel 2. Hasil Analisis Kompos Limbah Baglog

\begin{tabular}{lc}
\hline Unsur Hara & Kompos Baglog \\
\hline $\mathrm{pH}$ & 9.35 \\
$\mathrm{C}$-organik & $1.79 \%$ \\
$\mathrm{~N}$ & $1.20 \%$ \\
$\mathrm{C} / \mathrm{N}$ rasio & $1.00 \%$ \\
$\mathrm{P} 205$ & $0.81 \%$ \\
$\mathrm{~K} 20$ & $1.97 \%$ \\
$\mathrm{Ca}$ & $1.87 \%$ \\
$\mathrm{Mg}$ & $0.57 \%$ \\
$\mathrm{Fe}$ & $7485.34 \mathrm{ppm}$ \\
$\mathrm{Cu}$ & $38.10 \mathrm{ppm}$ \\
$\mathrm{Zn}$ & $130.50 \mathrm{ppm}$ \\
$\mathrm{B}$ & $181.42 \mathrm{ppm}$ \\
$\mathrm{S}$ & $0.14 \%$ \\
$\mathrm{~Pb}$ & $13.80 \mathrm{ppm}$ \\
\hline
\end{tabular}

\section{2) Biobriket Limbah Baglog}

Limbah baglog masih mengandung lignin, selulose dan hemiselulose yang cukup (Tabel 3) sehingga dapat dimanfaatkan sebagai bahan baku biobriket. Seperti yang dikemukakan Dharma (2013) bahwa briket limbah baglog mempunyai nilai kalor sebesar $3306 \mathrm{kal} / \mathrm{g}$ pada tekanan kempa pencetakan $100 \mathrm{~kg} / \mathrm{cm} 2$. Nilai kalor briket dapat ditingkatkan dengan cara menambahkan bahan lain yang mempunyai nilai kalor lebih tinggi (Yuniarti, dkk., 2011). Sebagai contoh briket arang serbuk gergaji kayu meranti yang mempunyai nilai kalor $6001 \mathrm{kal} / \mathrm{g}$, jika ditambahkan dengan 20\% arang kayu galam akan meningkat menjadi $6109 \mathrm{kal} / \mathrm{g}$. Pembuatan biobriket diawali dengan proses karbonisasi atau pengarangan limbah baglog. Arang karbonisasi kemudian dihaluskan dan diayak. Hasil ayakan dicampur dengan perekat kanji sebanyak $10 \%$ dari berat arang limbah yang digunakan. Pada tahap pencampuran ini dapat ditambahkan bahan lain (serbuk arang sekam padi, atau serbuk arang limbah gergaji, atau bubur kertas). Selanjutnya dilakukan pencetakan menjadi biobriket dan dijemur untuk pengeringan. Biobriket siap dipakai sebagai bahan bakar. 


\section{KESIMPULAN}

a) Pemanfaatan limbah baglog yang selama ini dianggap sebagai sampah atau produk yang tidak berguna membangkitkan minat petani jamur menjadikan limbah baglog sebagai kompos organik, pakan ternak ataupun sebagai bahan bakar dalam bentuk biobriket sesuai dengan kebutuhan petani jamur.

b) Penanganan limbah baglog hasil budidaya jamur tiram menjadi suatu produk dapat mengurangi pencemaran lingkungan

c) Produk limbah baglog dapat diproduksi secara komersial untuk menambah pendapatan petani jamur

d) Pengembangan produksi limbah baglog secara komersial diperlukan ketekunan dan kreativitas petani serta link untuk pemasaran.

\section{UCAPAN TERIMA KASIH}

Penulis mengucapkan terima kasih kepada LPPM Universitas Merdeka Madiun yang telah mendukung secara finansial. Terimakasih pula disampaikan kepada kelompok petani jamur Rejotani dan Mulyotani yang berpartisipasi mengurangi pencemaran lingkungan.

\section{DAFTAR PUSTAKA}

Dharma, U. S. (2013). Pemanfaatan Biomassa Limbah Jamur Tiram sebagai Bahan Bakar Alternatif Untuk Proses Sterilisasi Jamur Tiram. Turbo 2(2):18-22 https://ojs.ummetro.ac.id/index.php/turbo/article/view/642/457

Farhad, H. (2013). Mendaur Ulang Limbah Baglog Jamur. Diakses tanggal 24 Januari 2017 dari http://carasendiri.blogspot.com/search/label/Limbah\%20Media.

Hadiprayitno, G., Ilhamdi, M.L., Rasmi, D.A.C., dan Mertha, I.G. (2018). Pelatihan Kultivasi Jamur Tiram (Pleurotus florida) Ramah Lingkungan dengan Daur Ulang Limbah Substrat Jamur dan Penambahan Pupuk Organik Cair (POC) di Kecamatan Narmada. Jurnal Pendidikan dan Pengabdian Masyarakat 1 (1): 132 -139 http://jurnalfkip.unram.ac.id/index.php/JPPM/article/view/504/449

Hunaepi, Samsuri, T., dan Dharmawibawa, I.D. (2014). Pemanfaatan Limbah Media Jamur Sebagai Pupuk Organik (IbM Kelompok Tani). Jurnal Ilmiah IKIP Mataram. 1(2): 187-196 https://adoc.tips/pemanfaatan-limbah-media-jamur-sebagai-sebagai-pupuk-organik.html

Indriani, H. Y. (2011). Pembuatan Pupuk Kilat. Jakarta: Penerbit Penebar Swadaya

Jazuri. (2013). Budidaya Jamur Kuping. Diakses tanggal 7 Agustus 2018 dari http://doublejspizzeria.com/tag/budidaya-jamur-kuping/.

Muchlisin. (2013). Membedah Komposisi Media Tanam Jamur. Diakses tanggal 17 November 2017 dari http://cincinjamurmurah.blogspot.com/p/membedah-komposisi-media-tanambaglog $19 . \mathrm{html}$

Priyanto, A. (2013). Mengolah Limbah Baglog Menjadi Pupuk. Diakses pada tanggal 10 Juli 2015. http://bibitsuung.blogspot.com/2013/07/mengolah-limbah-baglog-menjadi-pupuk.html

Redaksi Trubus. (2014). Pacu Produksi Jamur Tiram. Trubus Swadaya. Depok. Hal. 27-41 http://trubus-online.co.id/belanja/product/pacu-produksi-jamur-tiram/

Rosmauli, Gofar, N., dan Hanum, L. . (2015). Pemanfaatan Kompos Dari Limbah Baglog Jamur Tiram (Pleurotus ostreatus) Sebagai Media Tumbuh Tanaman Sawi Hijau (Brassica rapa var. parachinensis L.). Jurnal Teknik Lingkungan UNAND 12 (2) : 120-126. https://docplayer.info/93053694-Pemanfaatan-kompos-dari-limbah-baglog-jamur-tirampleurotusostreatus-sebagai-media-tumbuh-tanaman-sawi-hijau-brassica-rapa-varparachinensis-l.html 
Rubiyah, S. 2012. Pemanfaatan Limbah Baglog Jamur Tiram. Diakses 20 Januari 2019 dari http://pertanianasahan.blogspot.com/2012/04/pemanfaatan-limbah-baglog-jamurtiram 20.html.

Sobari, E., Hadi, M.A., dan Fathurohman, F. (2018). Respon Pemberian Kompos Limbah Baglog Jamur dan Pupuk Kandang Domba Terhadap Pertumbuhan dan Hasil Kacang Tanah ( Arachis hypogaea L.). Prosiding Peran Penelitian dan Inovasi di Era Industri 4.0 dalam Mewujudkan Pembangunan Berkelanjutan Menuju Kemandirian Bangsa. Politeknik Negeri Bandung. https://pdfs.semanticscholar.org/be75/c5d16d8a1863897a078c33ad604d6bc42fa0.pdf?. g $\underline{a}=2.125185998 .558267958 .1$

Sulaeman, D. (2011). Efek Kompos Limbah Baglog Jamur Tiram Putih (Pleurotus ostreatus Jacquin) Terhadap Sifat Fisik Tanah Serta Pertumbuhan Bibit Markisa Kuning (Passiflora edulis var. Flavicarpa Degner). Skripsi. Fakultas Pertanian. Institut Pertanian Bogor. Bogor. https://repository.ipb.ac.id/ispui/bitstream/123456789/53343/1/A11dsu.pdf

Susi, N., Rizal, M., dan Mutryarny, E. (2017). Pelatihan Pegolahan Jamur Tiram di Kelurahan Tangkerang Tengah Kecamatan Marpoyan Damai Kota Pekanbaru. Jurnal Dinamsia, 1(1):7983 https://journal.unilak.ac.id/index.php/dinamisia/article/view/421/295

Triyanto. (2018). Mengolah Limbah Baglog Jamur Tiram Menjadi Produk Baru. Diakses tangal 24 Juni 2019 https://kabartani.com/mengolah-limbah-baglog-jamur-tiram-menjadi-produkbaru.html

. Warta K. (2014). Kandungan Nitrogen (N), Fosfor (P) Dan Kalium (K) Limbah Baglog Jamur Tiram (Pleurotus ostreatus) Dan Jamur Kuping (Auricularia auricula) Guna Pemanfaatannya Sebagai Pupuk. Skripsi. Fakultas Peternakan. Universitas Hasanuddin. Makassar https://docplayer.info/39281300-Kandungan-nitrogen-n-fosfor-p-dan-kalium-k-limbahbaglog-jamur-tiram.html

Yuniarti, Y. P., Theo, Y., Faizal., \& Arhamsyah, 2011. Briket Arang dari Serbuk Gergajian Kayu Meranti dan Kayu Galam. J. Ris. Ind. Has. Hutan, 3(2), 38-43

http://ejournal.kemenperin.go.id/jrihh/article/view/1194/1012 